\title{
Irfani
}

ISSN 1907-0969 E ISSN 2442-8272

Volume 15 Nomor 1 Juni 2019

Halaman 122-131

http://journal.iaingorontalo.ac.id/index.php/ir

\section{Evaluasi Pengelolaan Kurikulum Dalam Meningkatkan Mutu Pendidikan di Sdit Al-Izzah Kabupaten Pohuwato}

\author{
Sufiati $^{1}$, Arten Mobonggi $^{2}$, Munirah $^{3}$ \\ ${ }^{123}$ Pascasarjana IAIN Sultan Amai Gorontalo \\ Email: irawaty@gmail.com
}

\begin{abstract}
ABSTRAK
Artikel ini bertujuan untuk mengetahui bagaimana hasil evaluasi pengelolaan kurikulum dalam meningkatkan mutu pendidikan di SDIT Al-Izzah Kabupaten Pohuwato dan apa saja factor pendukung dan penghambat evaluasi pengelolaan kurikulum dalam meningkatkan mutu pendidikan di SDIT Al-Izzah Kabupaten Pohuwato. Metode yang digunakan adalah penelitian kualitatif, dengan teknik pengumpulan data melalui observasi, wawancara, dan dokumentasi. Hasil dari penelitian ini adalah problem evaluasi pengelolaan kurikulum di Sekolah Dasar Islam Terpadu (SDIT) AL-Izzah sudah bisa diatasi dengan baik. Hal ini didasarkan pada pengamatan peneliti terhadap kondisi dan realitas yang ada dilapangan. Meskipun berbagai macam kendalayang dihadapi SDIT AL Izzah Pohuwato tidak menyurutkan semangat elemen sekolah dalam meningkatkan kualitas pendidikan. Untuk mengatasi semua kendala yang ada, pihak sekolah mempunyai strategi dan pemikiran yang matang mengenai alternatif yang akan dilakukan sebagai upaya meminimalisir kendala yang ada agar peningkatan kualitas pendidikan yang dilaksanakan pihak sekolah dapat berjalan dengan lancar
\end{abstract}

Kata Kunci: Evaluasi, Kurikulum, Mutu Pendidikan.

\section{PENDAHULUAN}

Sekolah merupakan salah satu institusi sosial yang memiliki peran strategis dalam pembinaan kepribadian anak. Di dalam sekolah terjadi proses transformasi kebudayaan kepada anak. Tentu saja, transformasi kebudayaan tersebut berlangsung melalui pembelajaran sesuai kurikulum yang berisikan berbagai bidang ilmu pengetahuan dan nilai-nilai yang berlaku di masyarakat. Untuk menjamin kelangsungan transformasi kebudayaan bangsa Indonesia maka dilakukan pengaturan sistem pendidikan nasional sebagaimana UU No. 20/2003 tentang SISDIKNAS. Keberadaan SDIT (Sekolah Dasar Islam Terpadu) sebagai sekolah umum berciri khas agama Islam, dituntut untuk mengembangkan kemampuan serta meningkatkan mutu kehidupan dan martabat manusia Indonesia. Kelancaran pelaksanaan pendidikan di SDIT 


\section{Irfani}

ISSN 1907-0969 E ISSN 2442-8272

Volume 15 Nomor 1 Juni 2019

Halaman 122-131

http://journal.iaingorontalo.ac.id/index.php/ir

sangat tergantung pada berfungsi tidaknya manajemen Sekolah. Hal ini menjadi tanggung jawab utama kepala sekolah SDIT, selain kepemimpinan kepala sekolah untuk mencapai sekolah yang berkualitas. SDIT adalah lembaga pendidikan Islam yang hadir di tengah- tengah dunia pendidikan Islam di Indonesia, karena berbagai alasan diantaranya, sebagai manifestasi dan realisasi cita-cita pembaharuan dalam system pendidikan di Indonesia serta sebagai salah satu usaha menyempurnakan system pendidikan Indonesia. ${ }^{1}$

Maksud dan tujuan peningkatan mutu pendidikan pada SDIT adalah agar tingkat mata pelajaran umum dari SDIT mencapai tingkat yang sama dengan tingkat mata pelajaran umum di Sekolah Umum yang setingkat, sehingga ijazah SDIT dapat mempunyai nilai sama dengan ijazah Sekolah Umum yang setingkat, lulusan SDIT dapat melanjutkan ke sekolah Umum setingkat lebih atas, dan siswa SDIT dapat berpindah ke Sekolah umum yang setingkat. $^{2}$

Salah satu masalah yang dihadapi dunia pendidikan kita adalah masalah lemahnya proses pembelajaran. Dalam proses pembelajaran, anak kurang didorong untuk mengembangkan kemampuan berpikir. Proses pembelajaran di dalam kelas di arahkan kepada kemampuan anak mengingat dan menimbun berbagai informasi tanpa di tuntut untuk memahami informasi yang di ingatnya itu untuk menghubungkannya dengan kehidupan seharihari. ${ }^{3}$ Ada beberapa persoalan yang selama ini dihadapi guru dalam pendidikan dan pembelajaran di SDIT AL Izzah Kabupaten Pohuwato di antaranya: Kurikulum yang ada di sekolah hanya di anggap sebagai ramburambu mengajar, Guru menggunakan kurikulum “taken for granted” langsung jadi, sehingga kurikulum bukan kreatifitas guru untuk memberikan proses pembelajaran yang terbaik kepada siswa, tetapi sebagai tertib administrasi semata, Guru tidak memahami kurikulum, sehingga saat ada perubahan dari kurikulum KBK menuju KTSP tidak ada perubahan yang signifikan. Yang disebabkan tidak adanya kemandirian sekolah dan diperparah oleh lemahnya sumber daya manusia. Padahal tujuan dari KTSP adalah adanya kemandirian guru. ${ }^{4}$

Lemahnya proses pembelajaran yang dikembangkan guru dewasa ini, merupakan salah satu masalah yang dihadapi di dunia pendidikan kita. Proses

\footnotetext{
${ }^{1}$ Sutrisno, Pendidikan Islam yang Menghidupkan (Yogyakarta:Kota Kembang, 2006 Hal:30

${ }^{2}$ Ibid, Hal 30

${ }^{3}$ Wbinda Sadjalya, Strategi Pembelajaran beriorentasi Standar Proses Pendidikan, (Jakarta:Kencana ${ }^{3}$ Wina Sanjaya, Strategi Pembelajaran beriorentasi Standar Proses Pendidikan, (Jakarta:Kencana 2007) Hal : 1

${ }^{4}$ http://www.Google Manajemen Kurikulum.Go.Id di akses pada tanggal 23 febuari 2019
} 


\section{Irfani}

ISSN 1907-0969 E ISSN 2442-8272

Volume 15 Nomor 1 Juni 2019

Halaman 122-131

http://journal.iaingorontalo.ac.id/index.php/ir

pembelajaran yang terjadi di dalam kelas di laksanakan sesuai dengan kemampuan dan selera guru. Padahal pada kenyataanya kemampuan guru dalam pengelolaan pembelajaran tidak merata sesuai dengan latar belakang pendidikan guru serta motivasi dan kecintaan mereka terhadap profesinya. Ada guru yang melaksanakan pengelolaan pembelajarannya di lakukan dengan sungguh-sungguh melalui perencanaan yang matang, dengan memanfaatkan seluruh sumber daya yang ada dan memperhatikan taraf perkembangan intelektual dan perkembangan psikologi belajar anak. Guru yang demikian akan dapat menghasilkan kualitas lulusan yang lebih tinggi dibandingkan dengan guru yang dalam pengelolaan pembelajarannya dilakukan seadanya tanpa mempertimbangkan berbagai faktor yang bisa memengaruhi keberhasilan proses pembelajaran. ${ }^{5}$

Dalam setiap lembaga diperlukan yang namanya evaluasi pengelolaan kurikulum dalam upaya meningkatkan mutu pendidikan yang merupakan salah satu komponen vital sebuah lembaga pendidikan. Mekanisme evaluasi kurikulum yang jelek akan sangat berpengaruh terhadap mutu atau out-putnya. Pendidikan dapat dikatakan berkualitas jika berhasil mengeluarkan out-put atau lulusan yang sesuai dengan tujuan atau cita-cita pendidikan itu sendiri, sedangkan untuk merealisasikan tujuan pendidikan dalam proses pendidikannya banyak kendala yang dihadapi oleh manajer dalam hal ini adalah kepala sekolah. Untuk mencapai tujuan tersebut secara efektif dan efisien, maka diperlukan diantaranya adanya pengelolaan kurikulum dalam meningkatkan mutu pendidikan yang professional.

\section{METODE PENELITIAN}

Jenis penelitian yang digunakan adalah penelitian kualitatif. Menurut Bogdan dan Taylor yang dikutip oleh Moleong, pendekatan kualitatif merupakan suatu prosedur penelitian yang menghasilkan data deskriftif berupa kata-kata tertulis atau lisan dari orang-orang dan perilaku yang diamati. ${ }^{6}$ Pendekatan ini diterapkan untuk melihat dan memahami subjek dan objek penelitian (seseorang, lembaga, masyarakat dan sebagainya) berdasarkan fakta yang tampil secara apa adanya. Selanjutnya pengumpulan data penelitian ini dilakukan dengan teknik pengumpulan data melalui observasi, wawancara dan dokumentasi.

\section{PENGERTIAN EVALUASI}

\footnotetext{
${ }^{5}$ Wina Sanjaya, Strategi Pembelajaran Hal: 5

${ }^{6}$ Lexy J. Moloeng, MetodePenelitian Kualitatif, (Bandung :Remaja Rosdakarya,2000), h.
} 3. 


\section{Irfani}

ISSN 1907-0969 E ISSN 2442-8272

Volume 15 Nomor 1 Juni 2019

Halaman 122-131

http://journal.iaingorontalo.ac.id/index.php/ir

Evaluasi merupakan bagian dari sistem manajemen yaitu perencanaan, organisasi, pelaksanaan, monitoring dan evaluasi. Tanpa evaluasi, maka tidak akan diketahui bagaimana kondisi objek evaluasi tersebut dalam rancangan, pelaksanaan serta hasilnya. Istilah evaluasi sudah menjadi kosa kata dalam bahasa Indonesia, akan tetapi kata ini adalah kata serapan dari bahasa Inggris yaitu evaluation yang berarti penilaian atau penaksiran (Echols dan Shadily, 2000 : 220). Sedangkan menurut pengertian istilah "evaluasi merupakan kegiatan yang terencana untuk mengetahui keadaan sesuatu obyek dengan menggunakan instrumen dan hasilnya dibandingkan dengan tolak ukur untuk memperoleh kesimpulan"7

Pemahaman mengenai pengertian evaluasi dapat berbeda-beda sesuai dengan pengertian evaluasi yang bervariatif oleh para pakar evaluasi. Menurut Stufflebeam dalam Lababa (2008), evaluasi adalah "the process of delineating, obtaining, and providing useful information for judging decision alternatives," Artinya evaluasi merupakan proses menggambarkan, memperoleh, dan menyajikan informasi yang berguna untuk merumuskan suatu alternatif keputusan. Masih dalam Lababa (2008), Worthen dan Sanders mendefenisikan "evaluasi sebagai usaha mencari sesuatu yang berharga (worth). ${ }^{8}$

Pendapat lain mengenai evaluasi disampaikan oleh Arikunto dan Cepi (2008 : 2), bahwa:Evaluasi adalah kegiatan untuk mengumpulkan informasi tentang bekerjanya sesuatu, yang selanjutnya informasi tersebut digunakan untuk menentukan alternatif yang tepat dalam mengambil sebuah keputusan. Fungsi utama evaluasi dalam hal ini adalah menyediakan informasi-informasi yang berguna bagi pihak decision maker untuk menentukan kebijakan yang akan diambil berdasarkan evaluasi yang telah dilakukan. Sedangkan Uzer (2003 : 120), mengatakan bahwa: Evaluasi adalah suatu proses yang ditempuh seseorang untuk memperoleh informasi yang berguna untuk menentukan mana dari dua hal atau lebih yang merupakan alternatif yang diinginkan, karena penentuan atau keputusan semacam ini tidak diambil secara acak, maka alternatifalternatif itu harus diberi nilai relatif, karenanya pemberian nilai itu harus memerlukan pertimbangan yang rasional berdasarkan informasi untuk proses pengambilan keputusan. Menurut Djaali dan Pudji (2008 : 1), evaluasi dapat juga diartikan sebagai "proses menilai sesuatu berdasarkan kriteria atau tujuan yang telah

\footnotetext{
${ }^{7}$ Yunanda, M. 2009. Evaluasi Pendidikan. Jakarta : Balai Puataka.

${ }^{8}$ Stufflebeam. (http//www.tamucommerence.edu/counseling/faculty/leddick/images /CIPPmodel). 24 mei 2009.
} 


\section{Irfani}

ISSN 1907-0969 E ISSN 2442-8272

Volume 15 Nomor 1 Juni 2019

Halaman 122-131

http://journal.iaingorontalo.ac.id/index.php/ir

ditetapkan yang selanjutnya diikuti dengan pengambilan keputusan atas obyek yang dievaluasi". 9

Sedangkan Ahmad (2007 : 133), mengatakan bahwa "evaluasi diartikan sebagai proses sistematis untuk menentukan nilai sesuatu (ketentuan, kegiatan, keputusan, unjuk kerja, proses, orang, obyek, dan lain-lain.) berdasarkan kriteria tertentu melalui penilaian". Untuk menentukan nilai sesuatu dengan cara membandingkan dengan kriteria, evaluator dapat langsung membandingkan dengan kriteria namun dapat pula melakukan pengukuran terhadap sesuatu yang dievaluasi kemudian baru membandingkannya dengan kriteria. Dengan demikian evaluasi tidak selalu melalui proses mengukur baru melakukan proses menilai tetapi dapat pula evaluasi langsung melalui penilaian saja. Hal ini sejalan dengan apa yang dikemukakan Crawford (2000 : 13), mengartikan penilaian sebagai suatu proses untuk mengetahui/menguji apakah suatu kegiatan, proses kegiatan, keluaran suatu program telah sesuai dengan tujuan atau kriteria yang telah ditentukan. ${ }^{10}$

\section{STRATEGI MANAJEMEN KURIKULUM SEBAGAI UPAYA PENINGKATAN KUALITAS PENDIDIKAN}

Secara umum strategi mempunyai suatu pengertian suatu garis-garis besar atau haluan untuk bertindak dalam usaha mencapai sasaran yang telah ditentukan. Dalam rangka peningkatan mutu atau kualitas pendidikan, perlu dilakukan berbagai strategi diantaranya adalah:

1. Pengembangan kurikulum termasuk cara penyajian pelajaran dan sistem study pada umumnya.

2. Pengadaan buku-buku pelajaran pokok untuk murid serta buku pedoman guru sekolah dasar dan sekolah-sekolah lanjutan, buku-buku pelajaran kejujuran dan tehknik untuk sekolah-sekolah yang memerlukannya dan buku-buku perpustakaan dalam berbagai bidang studi pada pendidikan tinggi.

3. Pengadaan alat-alat peraga dan alat-alat pendidikan lainnya pada sekolah dasar (SD), TK, dan SLB, laboratorium IPA dan SMP \& SMA, fasilitas dan perlengkapan latihan dan praktik pada sekolah-sekolah kejuruan dan tehknik serta laboratorium untuk berbagai bidang ilmu pendidikan untuk perguruan tinggi.

\section{Penataran Guru-guru dan Dosen}

\footnotetext{
${ }^{9}$ Djaali \& Pudji Muljono. (2008). Pengukuran Dalam Bidang Pendidikan. Jakarta:PT. Grasindo

${ }^{10}$ Ahmad D. Marimba, 2007, Dasar-Dasar Evaluasi Pendidikan, Jakarta; Bumi Aksara
} 


\section{Irfani}

ISSN 1907-0969 E ISSN 2442-8272

Volume 15 Nomor 1 Juni 2019

Halaman 122-131

http://journal.iaingorontalo.ac.id/index.php/ir

5. Pengadaan buku bacaan yang sehat dan bermutu melalui perpustakaan sekolah. $^{11}$

Sekolah merupakan ujung tombak pelaksanaan kurikulum, baik kurikulum nasional maupun muatan lokal, yang diwujud kan dalam proses belajar mengajar untuk mencapai tujuan pendidikan nasional, institusional, kurikuler dan instruksional. Agar proses belajar mengajar dapat dilaksanakan secara efektif dan efisien serta mencapai hasil yang diharapkan, maka diperlukan kegiatan manajemen program pengajaran. Manajemen atau administrasi pengajaran adalah keseluruhan proses penyelenggaraan kegiatan dibidang pengajaran yang bertujuan agar seluruh kegiatan pengajaran terlaksana secara efektif dan efisien. ${ }^{12}$

Diantara komponen pokok sistem pendidikan, yaitu berupa masukan sumber, proses pendidikan dan hasil pendidikan. Ketiga komponen tersebut memang saling berkaitan dan saling mempengaruhi, namun yang paling berpengaruh terhadap output adalah proses pendidikan, artinya walaupun masukan sumber kurang bermutu atau berkualitas, tetapi apabila diproses dengan proses pendidikan yang bermutu, maka akan dapat menghasilkan output yang berkualitas pula.

\section{HASIL DAN PEMBAHASAN}

Pelaksanaan evaluasi pengelolaan kurikulum di SDIT AL Izzah Kabupaten Pohuwato juga bertujuan untuk mengoptimalkan proses belajar mengajar di sekolah, sehingga proses belajar mengajar dapat berjalan dengan efektif. Dalam meningkatkan kualitas pendidikan, pihak sekolah membuat program yang sebelumnya telah dianalisis dan didiskusikan bersama dengan guru dan staf. Hal ini dilakukan agar semua elemen yang ada disekolah mengetahui dan ikut berperan serta dalam pelaksanaan program. Dalam proses evaluasi pengelolaan terdapat empat hal pokok, yaitu perencanaan, pengorganisasian, pelaksanaan dan pengawasan atau evaluasi. Perencanaan merupakan hal yang sangat penting ketika akan melaksanakan suatu kegiatan.

Dengan adanya perencanaan yang jelas, maka diharapkan program pembelajaran yang ada disekolah dapat dicapai dengan maksimal. Setelah proses perencanaan sekolah secara umum ditetapkan dalam rapat, maka proses perencanaan selanjutnya adalah perencanaan program pembelajaran selama satu semester atau satu tahun. Proses perencanaan ini merupakan kegiatan yang

\footnotetext{
${ }^{11}$ Wasty. Soemanto. F.X. Soeyamo, Landasan Historis Pendidikan Indonesia (Surabaya: Usaha Nasional , 1993), hlm:111

${ }^{12}$ Mulyasa, Manajemen Berbasis Sekolah, Konsep, Strategi dan Implementasi (Bandung: Remaja Rosda Karya, 2005), hml:41
} 


\section{Irfani}

ISSN 1907-0969 E ISSN 2442-8272

Volume 15 Nomor 1 Juni 2019

Halaman 122-131

http://journal.iaingorontalo.ac.id/index.php/ir

dilakukan oleh guru-guru dalam proses pembelajaran seperti membuat prota, promes, rencana pembelajaran, silabus dan lain-lain.

Dalam tahap pengorganisasian ini waka kurikulum di Sekolah Dasar Islam Terpadu (SDIT) AL-Izzah bertugas membuat jadwal mengajar guru, Pembagian tugas mengajar guru.. Penyusunan jadwal pelajaran diupayakan agar guru mengajar maksimal 5 hari dalam satu minggu. Penyusunan jadwal kegiatan perbaikan dan pengayaan bagi siswa yang belum tuntas penugasan terhadap bahan ajar. Penyusunan jadwal kegiatan ekstra kurikuler. Penyusunan jadwal penyegaran guru. Kegiatan ini dimaksudkan untuk penyegaran informasi pengetahuan guru tentang IPTEK dan atau model pembelajaran baru dalam pemanfaatan hari libur sekolah.

Inti dari pelaksanaan adalah merealisasikan segala hal yang telah disusun dalam perencanaan pembelajaran. Kaitannya dengan dengan fungsi pengorganisasian, kepala sekolah sebagai pemimpin bertugas untuk menjadikan kegiatan-kegiatan sekolah yang menjadi tujuan sekolah dapat berjalan dengan lancar. Dengan pembagian kerja yang baik, pelimpahan wewenang dan tanggung jawab yang tepat serta mengingat prinsip-prinsip pengorganisasian kiranya kegiatan sekolah akan berjalan dengan baik.

Pelaksanaan kegiatan belajar mengajar di Sekolah Dasar Islam Terpadu (SDIT) AL-Izzah sudah relatif lancar. Hal ini sesuai dengan hasil observasi yang dilakukan oleh peneliti bahwasanya kegiatan belajar mengajar dilaksanakan mulai pukul 07.00 WIB dan pulang pada pukul 15.30 WIB dengan dua kali istirahat, dan siswa siswi juga dibiasakan untuk untuk melaksanakan sholat dhuha berjamaah dimasjid sekolah dan juga mengikuti Muroja'ah Hafalan setiap pagi sebelum kegiatan belajar mengajar berlangsung.

Dalam pelaksanaan evaluasi pengelolaan kurikulum. Evaluasi kurikulum memegang peranan penting baik dalam penentuan kebijaksanaan pendidikan pada umumnya maupun pada pengambilan keputusan dalam kurikulum. Hasil-hasil evaluasi kurikulum juga dapat digunakan oleh guru-guru dan kepala sekolah dalam memahami dan membantu perkembangan siswa, memilih bahan pelajaran, memilih metode dan alat-alat bantu pelajaran, cara penilaian serta fasilitas pendidikan lainnya.

Evaluasi kurikulum bukan hanya mengevaluasi hasil belajar siswa dan proses pembelajarannya, kemampuan unjuk kerja guru, kemampuan dan kemajuan siswa, sarana, fasilitas dan sumber-sumber belajar lainnya. Berdasarkan teori tersebut, pelaksanaan evaluasi proses belajar mengajar di Sekolah Dasar Islam Terpadu (SDIT) AL-Izzah ini dilakukan dengan evaluasi formatif dan sumatif. Pelaksanaan evaluasi ini tidak hanya ditujukan untuk siswa saja, akan tetapi juga pada guru yaitu bagaimana pelaksanaan proses belajar mengajar 


\section{Irfani}

ISSN 1907-0969 E ISSN 2442-8272

Volume 15 Nomor 1 Juni 2019

Halaman 122-131

http://journal.iaingorontalo.ac.id/index.php/ir

dikelas apakah sudah efektif apa belum, metode yang digunakan sesuai atau tidak, kemampuan guru dalam menyusun rencana pembelajaran dan silabus, kemudian media dan sarana prasarana apa yang dirasakan kurang, dari semua problem diatas itu maka akan dimusyawarahkan untuk dicarikan solusi pemecahannya, karena semua itu akan mendukung proses belajar mengajar untuk yang akan datang.

Peningkatan kualitas pendidikan bukanlah tugas yang ringan karena tidak hanya berkaitan dengan permasalahan teknis, tetapi mencakup berbagai persoalan yang sangat rumit dan kompleks, baik yang menyangkut perencanaan, pendanaan, maupun efisiensi dan efektifitas penyelenggaraan sistem sekolah. Peningkatan kualitas pendidikan juga menuntut manajemen pendidikan yang lebih baik, khususnya manajemen sekolah.

Dalam rangka peningkatan mutu atau kualitas pendidikan, perlu dilakukan berbagai strategi diantaranya adalah :

1. Pengembangan kurikulum termasuk cara penyajian pelajaran dan sistem studi pada umumnya

2. Pengadaan buku-buku pelajaran pokok untuk murid serta buku pedoman guru sekolah dasar dan sekolah-sekolah lanjutan, buku-buku pelajaran kejuruan dan tehnik untuk sekolahsekolah yang memerlukannya dan buku-buku perpustakaan dalam berbagai bidang studi pada pendidikan tinggi

3. Pengadaan alat-alat peraga dan alat-alat pendidikan lainnya pada sekolah dasar (SD), TK, dan SLB, laboratorium IPA dan SMP\&SMA, fasilitas dan perlengkapan latihan dan praktik pada sekolah-sekolah kejuruan dan tehnik serta laboratorium untuk berbagai bidang ilmu pendidikan untuk perguruan tinggi

4. Penataran guru-guru dan dosen

5. Pengadaan buku bacaan yang sehat dan bermutu melalui perpustakaan sekolah.

Sesuai dengan teori diatas, evaluasi pengelolaan kurikulum di Sekolah Dasar Islam Terpadu (SDIT) AL-Izzah juga mempunyai strategi untuk meningkatkan kualitas pendidikannya, strateginya antara lain adalah: Pengelolaan kegiatan pembelajaran dalam mata pelajaran dan kegiatan belajar pembiasaan diorganisasikan sepenuhnya oleh sekolah atau yayasan menggunakan metode pembelajaran yang bervariasi, mengadakan kegiatan rombongan belajar, pengadaan buku pedoman bagi guru dan siswa, melaksanakan kegiatan remedi, kegiatan belajar mengajar dapat dilaksanakan diluar kelas, misalnya perpustakaan, 


\section{Irfani}

ISSN 1907-0969 E ISSN 2442-8272

Volume 15 Nomor 1 Juni 2019

Halaman 122-131

http://journal.iaingorontalo.ac.id/index.php/ir

masjid dan lain-lain, mengenalkan teknologi kepada siswa yaitu komputer agar siswa bisa menggunakan dan memanfaatkannya.

Strategi peningkatan kualitas pendidikan yang ada di Sekolah Dasar Islam Terpadu (SDIT) AL-Izzah tidak hanya pada evaluasi pengelolaan kurikulumnya saja akan tetapi juga dari segi yang lain, yaitu:

1. Dari segi guru

Sebagai pendidik profesional guru bukan saja dituntut untuk melaksanakan tugasnya secara profesional, tetapi juga harus memiliki pengetahuan dan kemampuan profesional, maka upaya yang dilakukan oleh Sekolah dalam meningkatkan profesionalisme guru adalah dengan mengikuti seminar, lokakarya,stuband, musyawarah guru mata pelajaran dan lain- lain yang sekiranya dapat menunjang profesionalisme guru.

2. Dari segi siswa atau peserta didik

Peserta didik merupakan suatu faktor atau komponen dalam pendidikan. karena itu pembinaan terhadap anak harus dilaksanakan secara terus menerus kearah kematangan dan kedewasaan, oleh karena itu siswa harus dilibatkan secara aktif dalam setiap pelaksanaan kegiatan belajar mengajar.

\section{Dari segi sarana prasarana}

Sarana pendidikan adalah peralatan dan perlengkapan yang secara langsung dipergunakan dan menunjang proses pendidikan. Peningkatan yang dilakukan SDIT AL Izzah Kabupaten Pohuwato yaitu dengan pengadaan sarana prasarana baru secara bertahap dan terencana, rehabilitasi sarana prasarana yang ada, melengkapi buku-buku pelajaran dan perpustakaan sekolah, pengadaan laboratorium bahasa, penyediaan media-media pelajaran, alat-alat olah raga, serta kelengkapan alat-alat kegiatan ekstrakurikuler baik kepramukaan maupun usaha kesehatan sekolah.

Dengan strategi evaluasi pengelolaan kurikulum yang dilaksanakan di Sekolah Dasar Islam Terpadu (SDIT) AL-Izzah ini diharapkan proses belajar mengajar dapat berjalan dengan baik dan siswa juga dapat menerima semua pelajaran yang diajarkan di sekolah sehingga dapat menghasilkan lulusan yang berkualitas. 


\section{Irfani}

ISSN 1907-0969 E ISSN 2442-8272

Volume 15 Nomor 1 Juni 2019

Halaman 122-131

http://journal.iaingorontalo.ac.id/index.php/ir

Pendidikan yang berkualitas adalah pendidikan yang dapat menghasilkan lulusan yang berkualitas yaitu lulusan yang memiliki prestasi akademik dan non akademik yang mampu menjadi pelopor pembaharuan dan perubahan sehingga mampu menjawab berbagai tantangan dan permasalahan yang dihadapinya baik di masa sekarang maupun yang akan datang.

\section{KESIMPULAN}

Dari hasil data yang diperoleh peneliti dilapangan maka dapat disimpulkan bahwa problem evaluasi pengelolaan kurikulum di Sekolah Dasar Islam Terpadu (SDIT) AL-Izzah sudah bisa diatasi dengan baik. Hal ini didasarkan pada pengamatan peneliti terhadap kondisi dan realitas yang ada dilapangan. Meskipun berbagai macam kendala yang dihadapi SDIT AL Izzah Pohuwato tidak menyurutkan semangat elemen sekolah dalam meningkatkan kualitas pendidikan. Untuk mengatasi semua kendala yang ada, pihak sekolah mempunyai strategi dan pemikiran yang matang mengenai alternatif yang akan dilakukan sebagai upaya meminimalisir kendala yang ada agar peningkatan kualitas pendidikan yang dilaksanakan pihak sekolah dapat berjalan dengan lancar.

\section{DAFTAR PUSTAKA}

Djaali \& Pudji Muljono, Pengukuran Dalam Bidang Pendidikan. Jakarta:PT. Grasindo, 2008.

http://www.Google Manajemen Kurikulum.Go.Id di akses pada tanggal 23 febuari 2019.

http//www.tamucommerence.edu/counseling/faculty/leddick/images /CIPPmodel). 24 mei 2009.

Moloeng, Lexy J. Metode Penelitian Kualitatif, Bandung :Remaja Rosdakarya,2000.

M. Yunanda. Evaluasi Pendidikan. Jakarta : Balai Pustaka, 2009.

Marimba, Ahmad D. Dasar-Dasar Evaluasi Pendidikan, Jakarta; Bumi Aksara, 2007.

Mulyasa, Manajemen Berbasis Sekolah, Konsep, Strategi dan Implementasi. Bandung: Remaja Rosda Karya, 2005.

Sutrisno, Pendidikan Islam yang Menghidupkan. Yogyakarta:Kota Kembang, 2006.

Sanjaya, Wina. Strategi Pembelajaran beriorentasi Standar Proses Pendidikan, Jakarta:Kencana 2007.

Soemanto. Wasty. F.X. Soeyamo, Landasan Historis Pendidikan Indonesia Surabaya: Usaha Nasional , 1993. 